\title{
Sociological perspective on the elimination of Karanganyar Regency as an impact of the 1930s economic depression
}

\author{
Teguh Hindarto ${ }^{1^{*}}$, Chusni Ansori ${ }^{2}$ \\ ${ }^{1}$ Braindilog Sosiologi Indonesia, Indonesia \\ ${ }^{2}$ Puslit Geoteknologi - LIPI, Indonesia \\ *Corresponding author \\ E-mail address: derekhatov@gmail.com \\ DOI: https://doi.org/10.21107/sml.v3i1.7201
}

\begin{tabular}{|c|c|}
\hline Article Info & Abstract \\
\hline $\begin{array}{l}\text { Keywords: } \\
\text { Economic crisis } \\
\text { Social-economical- } \\
\text { cultural-political } \\
\text { impact } \\
\text { Social change }\end{array}$ & $\begin{array}{l}\text { The 1930s economic crisis in the United States had spread throughout } \\
\text { the world and caused a number of social, economic, political and cultural } \\
\text { impacts, including for the Dutch East Indies colonies. Karanganyar Regency, } \\
\text { which was in the Bagelen Residency territory since 1901, had experienced } \\
\text { the effects of the economic shock as well. Karanganyar was a district in the } \\
\text { Kebumen Regency area. Before becoming a sub-district, Karanganyar was an } \\
\text { independent regency and had its head of government from } 1832 \text { until } 1936 . \\
\text { Through literature studies, this paper intended to thoroughly analyze the } \\
\text { existence of Karanganyar Regency in the colonial era, find out the background } \\
\text { of its elimination, and the process of social change that occurred. To obtain } \\
\text { the main variables that cause the elimination of Karanganyar Regency, the } \\
\text { researcher utilized the historical comparative method. From the analysis, } \\
\text { we concluded that the Economic Depression centred in the United States } \\
\text { affected the Dutch East Indies colonies, particularly on the management of } \\
\text { the government bureaucracy. This situation demanded the Dutch East Indies } \\
\text { government to adapt to social change by removing a number of Regency, } \\
\text { including Karanganyar Regency. }\end{array}$ \\
\hline
\end{tabular}

\section{Citation suggestion:}

Hindarto, T., \& Ansori, C. (2020). Sociological perspective on the elimination of Karanganyar Regency as an impact of the 1930s economic depression. Simulacra, 3(1), 81-94. https://doi.org/10.21107/sml.v3i1.7201

Received 6 May 2020; Received in revised form 23 May 2020; Accepted 29 May 2020; Published online 25 June 2020. 


\section{Introduction}

The Great Depression of 1929-1938 centered in the United States. It not only brought social, political, economic and cultural impact domestically but on all countries economically connected with the United States. It produces an effect akin to ocean floor earthquake that triggers tsunamis in some coastal areas close to the epicenter. The United States Economic Depression was an economic earthquake epicenter that triggered a tsunami effect in a number of countries. Indeed, the United States experienced the most severe shocks as the centre of the Economic Depression. In 1929, as many as 600 banks closed. In the following, the 1000 followed suit (McNesse, 2010: 39). In 1932, as many as 2000 banks in the United States went out of business (McNesse, 2010:39). Shocks wereexperienced in other business sectors, not only business people and bankers. Farmers felt similar economic shocks. In 1929, a bushel was valued at $\$ 1.03$. It fell drastically to 36 cents in 1931 (McNesse, 2010: 39). Unemployment increased dramatically. However, there was no accurate record from the federal government. In 1932, industrial workers' wages fell by 50\% since 1928 (McNesse, 2010: 39).

The economic depression which affected the United States and several other countries disrupt not only industrial and economic activities but also political and government policies. It also affected a number of colonies, including the Dutch East Indies (Indonesia). Budget cuts and elimination of certain administrative regions was a part of a policy to respond to the Economic Depression. From a sociological perspective, the Economic Depression of 1929-1938 gave rise to several unplanned and unintended changes in various sectors, including social, political, cultural, and primarily economic. This paper would provide a number of sociological descriptions and analyzes related to the impact of the Economic Depression in the Dutch East Indies, especially Karanganyar Regency, which has been part of the Bagelen Residency territory since 1901.

\section{Method}

Given that the topic of discussion examines an event that triggered social impacts and changes across countries, the most suitable methodology used to study the problem is the historicalcomparative approach to get a comprehensive understanding. As stated by W. Lawrence Neuwan, the historical comparative is suitable for examining various combinations of social factors that give certain results (for example, civil war, taxation system, and religion). This approach is also appropriate to compare the social system as a whole, to find issues that commonly found in all communities as well as unique ones, and to study the long-term changes that occur in society (Neuman, 2013: 513).

The steps of the historical-comparative approach are composed of conceptualizing the object of study, finding evidence, evaluating the quality of evidence, compiling evidence, synthesizing, and writing reports (Neuwan, 2013: 522-526). We took several methodological steps to obtain a general description of the Economic Depression that hit the world. It was described and analyzed through a number of historical data in the form of works of literature that capture the economic shocks. Meanwhile, the impact of the depression on the Dutch East Indies territories was be presented and analyzed through a number of historical data from Dutch-language newspapers that reported the removal and reaction of local officials in the Bagelen Residency and the Banyumas Residency.

The authors attempted to find the main factors that lead to the elimination of 
Karanganyar Regency to be merged into Kebumen Regency. After collecting several Dutch newspaper articles, the writer found a number of reasons for the elimination of many districts in the Bagelen and Banyumas, including Karanganyar Regency. To ensure the accuracy of colonial-era Dutchlanguage newspaper articles' translations, the author utilized several physical and virtual dictionaries and encyclopedias. Because this study examined the situation of an area that has undergone socio-cultural and socio-political and socio-economic changes, a historical review was necessary. We analyzed several reports from the Dutchlanguage newspaper. Historical studies were conducted to understand the socio-historical process behind an event, in this case, is the elimination of Karanganyar Regency and its incorporation into Kebumen Regency.

\section{Results and Discussion}

\section{Anatomy of Social Change}

According to August Comte, social life is like an organism. It has both static and dynamic aspects. Static aspects include elements that remain in society, such as social structures and social systems. Conversely, dynamic aspects include various developments or changes that support social life (Turner, 2014: 8). Social change that occurs in a society is a dynamic aspect of the community itself.

Social change is not just an event that shows a shift or change from one state to another. Instead, it has several anatomies that include factors that cause social change, the impact caused by social change, the direction of a social change, and some typologies that characterize a social transformation. Social change can be defined as a change that occurs in society, including behavior patterns, social relations, as well as institutions and social structures at a specified period. John J.
Macionis described four characteristics that mark a process of social change, namely: (1) Social change that occurs over time. Change is part of the dynamics of the life of a society; (2) social change often occurs continuously but sometimes unplanned. A deviation can occur from the original plan; (3) social change causes controversy. Every social change is not necessarily accepted and can experience a reaction of rejection because of unpreparedness; (4) social change becomes a problem for other parties. On the one hand, social change brings benefits, but for other groups, it becomes a loss (Macionis, 2014: 697).

To understand the complex problem of social change, a typology of social change is necessary. Piotr Sztompka defined the six typologies: (1) the form of occurring social processes, (2) the results of a social change processes, (3) the community members' awareness of social change process, (4) the driving forces of the process of change, (5) the reality level of a social change, (6) and the time of the social change (Sztompka, 2004: 13). Of the five typologies of social change, two things need to be highlighted as a theoretical foundation for social analysis in this article, namely 'awareness of the social change processes' and 'the driving forces of the social change process.' The process of social change involves several actors/agents who are aware of said process. It includes awareness of the results generated by social change. Robert Merton differentiated the 'processes that manifest (visible) or processes that are expected and realized' and 'latent processes' or processes that are not expected and are not realized (Merton, 1968: 73). He added a third process, which is 'boomerang processes' or processes that are realized and expected happened but missed (Merton, 1968: 105).

Some sociologists termed differently: 'intended change' (planned change) and 'unintended change', or 'unplanned change' 
(Soekanto, 2014: 272-273). Ram Ahuja's book, "Social Problems in India" (1992), presented an example of how the design of change had been established in India. Still, a number of deviations occurred and became social problems that inhibit changes in caste and underdeveloped classes (Ahuja, 1992: 103131), child abuse, child labour (Ahuja, 1992: 188-212), and gendered violence (Ahuja, 1992: 213-228)

Every social change has a causal force. A causal factor that occurs from within the system is called an 'endogenous process.' On the contrary, a causal factor that occurs from outside is called the 'exogenous process.' Georg Simmel analyzed the role of money as a driver of social change and fast-paced life in his book, "The Philosophy of Money" (2017). For Simmel, money 'transcends time' because it can overcome many temporal obstacles, both by nature and the business cycle (Wajcman, 2017: 14). In contrast, Marvin Perry outlined how the role of religion developing in the Near East (Mesopotamia, Egypt, Hitti, and Persia) 5000 years ago influenced civilization. It gave birth to social, political, economic and technological systems and structures (Perry, 2017: 10). Likewise, Max Weber believed that Protestantism was the driving force for the creation of the European Capitalism economy (Perry, 2006: 3). Selo Sumarjan analyzed how social change actors who caused social changes in Yogyakarta relied on the figure of Sultan Hamengkubuwono IX and several educated elite figures (Sumarjan, 2009: 448-459).

Robert K. Merton developed the Strain Theory to explain cultural goals and the inability of individuals to achieve what people want in these cultural goals. The inability of individuals to adjust and achieve cultural goals in the structure can lead to several tensions (strains) called 'anomie' (Merton, 1968: 11). Merton explained that there are five types of individual adaptation in facing cultural demands in the society, namely: Conformity, Innovation, Ritualism, Retreatism, and Resurrection (rebellion) (Merton, 1968: 194). Because society is a collection of individuals, the five types of adaptation can apply to a group of people.

Social change can cause some tensions and require every individual, social

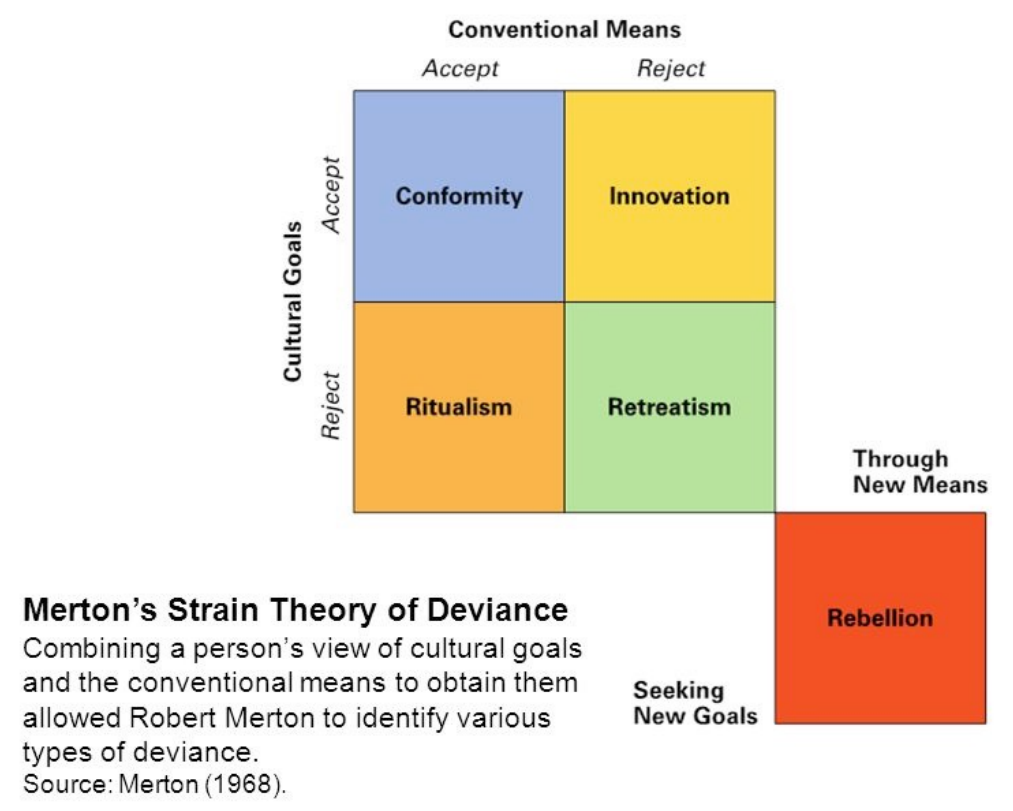

Figure 1. http://sociologylegacy.pbworks.com 
organization, political institution, economic institution to take adaptation actions that can lead to one of the five types of adaptation above.

\section{The World Economic Crisis of 1929-1938 and Its Impact on the Dutch East Indies}

An economic crisis shook the United States in 1929. American society dubbed it the 'Black Tuesday because 29 October 1929 fell on a Tuesday:

"That day, 16 million shares were traded, and the industrial stock index fell 43 points, destroying almost all profits made by the market during the previous 12 months. Some shares lost almost all of their value. During the week after 'Black Tuesday', the market continued to fall freely" (McNesse, 2010: 26).

The world terms of this economic collapse with various names. In the Dutch East Indies, the Great Depression was known as 'Malaise' or 'Age of Misses.' The term 'Malaise' appeared in a number of Dutch magazines (De Metaalbewerker, 1931) and newspapers (De Locomotief, 1932). The McNeese team listed a number of factors which caused Black Tuesday and the Great Depression in the United States in 1929. These factors include (1) Declining construction and car industries, (2) Poverty and credit issues, (3) International situations and debt, and (4) The gap between the rich and poor (McNesse, 2010: 27-31). These conditions eventually burst and destroyed all the country's economic foundations in the next few years. In addition to the above problems, Amity Shlaes put more blame on government intervention - President Hoover and President Roosevelt - on the market. She stated, "But the deepest problem was the intervention, the lack of faith in the marketplace" (Shlaes, 2007: 7). They were accused of raising wages while many were asking to be lowered and letting tariff restrictions become law rather than blocking it and raising taxes when many people are unable to pay it. As a result, industrial production slowed in America while other countries such as Japan, Chile, Denmark, Finland, Sweden have picked up.

Like a tsunami wave, the American Economic Depression affected not only on Europe but Africa and even Asia, including the Dutch East Indies (Indonesia before independence). In more detail, Soegijanto Padmo divided the impact of the Economic Depression in the Dutch East Indies into four aspects, namely: the collapse of international commodity prices and demand, problems in the cultivation of commercial crops (especially rubber and sugar), the financial crisis caused by reduced government revenue and spending and finally social-economic consequences from the sharp decline in employment, income and purchasing power in the country (Padmo, 1991: 151).

Susanto Zuhdi revealed the deterioration of the sugar and rubber commodity in Cilacap, which affected the number of exports at the Cilacap port. For example, rubber prices even dropped by $10 \%$ of the normal prices (Zuhdi, 2016: 69-70). Unlike sugar and rubber, coconut oil, and copra commodities were able to survive the Economic Depression and sustained exports from the Cilacap port (Zuhdi, 2016: 72-73). Sugarcane plantations experienced great difficulties because sugar reserves reached an alarming level in the 1930-1931 period while production had to be pruned. Prima Nurahmi Mulyasari reported that the closure of the Purwokerto Sugar Factory was influenced by the Economic Depression. The sugar factory was previously a health service donor for Vereeniging Kliniek Poerwokerto. After it went into bankruptcy on 1 January 1933, it was taken over by Zending and changed into Zendingziekenhuis te Poerwokerto (Mulyasari, 2014: 614) 
Colonial plantations in Java and East Sumatra experienced different impact. For East Sumatra, a number of coffee, tea, rubber, and sugar cane plantations decreased its production significantly. In 1930, 198,007 hectares of sugar cane was reduced to 27,575 hectares in 1935. Coffee plantations which covered an area of 97,520 hectares in 1930 were reduced to 96,460 in 1935 . In 1930, 182,169 hectares of tobacco plantations were reduced to 173,686 hectares in 1935 (Siswoyo et al., 2017).

\section{Economic Depression and Elimination of Karanganyar Regency}

In this study, Karanganyar referred to the area in Kebumen Regency. It is different from Karanganyar Regency, which is adjacent to the city of Surakarta (Solo), Boyolali Regency, Sragen Regency, and Ngawi Regency. One was a regency and one was a district status.

Karanganyar was a district in Kebumen Regency with an area of $31.40 \mathrm{~km}$. It was $14 \mathrm{~km}$ from Kebumen Regency and was composed of 4 sub-district and seven villages and a population of 34,363 inhabitants in 2018 (BPS Kebumen Regency, 2019: 5,7,20$21,43)$

\section{Geographical Condition}

The "Atlas van de Zending Steirreinen van de Gereformeede Kerken in the Netherlands" (1932) and other sources superimposed (overlay) with the R.B.I. Digital maps 2009 can be seen in the map in Figure 1. Karanganyar Regency was included in the South Banyumas Residency with the Indonesian Ocean as region southern boundary, Cilacap Regency-South Banyumas Residency in the western part, Banjarnegara Regency-North Banyumas Residency in the northern part, and Luk Ulo River which includes Bagelen Regency- Kebumen Residency in the eastern part: The comparison of the area and the mainland use from overlays with land use data in 2009 (Digital R.B.I. Map) between Karanganyar Regency are presented in Table 1 below.

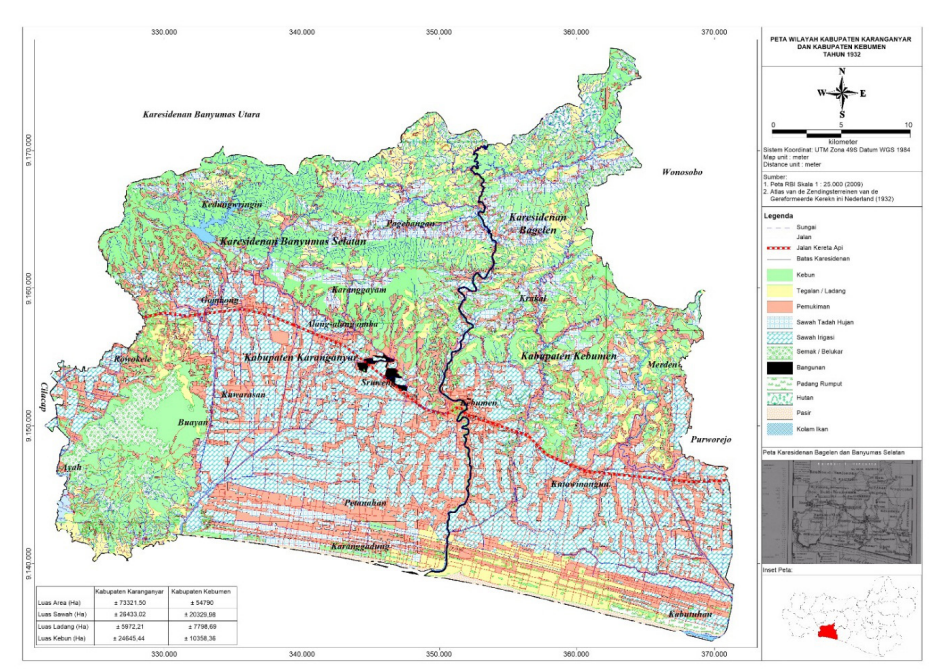

Figure 2. Map of the Karanganyar Regency, South Banyumas Regency, and Kebumen Regency in Bagelen Residency (1932) 
Table 1

The area and land use of Karanganyar and Kebumen Regency

\begin{tabular}{lcc}
\hline & $\begin{array}{c}\text { Karanganyar } \\
\text { Regency, } \\
\text { South } \\
\text { Banyumas } \\
\text { Residency }\end{array}$ & $\begin{array}{c}\text { Kebumen } \\
\text { Regency, } \\
\text { Bagelen } \\
\text { Residency }\end{array}$ \\
\hline Area $(\mathrm{Ha})$ & $73.321,50$ & $54.790,00$ \\
\hline Rice $(\mathrm{Ha})$ & $26.433,02$ & $20.329,98$ \\
\hline Field $(\mathrm{Ha})$ & $5.972,21$ & $7.798,69$ \\
\hline Garden $(\mathrm{Ha})$ & $24.645,44$ & $10.358,36$ \\
\hline
\end{tabular}

In terms of area size, the paddy fields and garden area of Karanganyar Regency was fuller than Kebumen. In the southern part of the region, there were walet bird nest production, as well as abundant tourism places and mining potential. Based on the area and economic potential, Karanganyar Regency was higher than Kebumen Regency.

\section{Karanganyar as Regency Post Java War}

In the colonial era, Karanganyar was a Regency that was part of the Bagelen Residency. After the defeat of the Java War (1825-1830) and the signing of a political contract on 27 September 1830, there was a re-administrative change in the Sultanate and the residences by the Dutch government where, "... separated from the royal domain and ruled by the Dutch government" (Paulus, 1917: 103). This period was called 'Nagari transition' in which some southern coastal regions of Bagelen and several fertile agricultural areas were annexed by the Dutch government. The Bagelen region, which was a foreign territory, was then made into a residency by the placement of a Resident Assistant. Bagelen became a Residency area until 1 August 1901 and was later merged into the Kedu Residency.

The Bagelen Residency oversaw 5 Regentschap (Regencies) consisting of Regentschap Purworejo, Regentschap Kutoarjo, Regentschap Kebumen, Regentschap Karanganyar, Regentschap Ledok. Regentschap Purworejo had three districts namely Purworejo, Loano, Cangkreb. Regentschap Kutoarjo had five districts namely Kutoarjo, Kemiri, Pituruh, Jenar, Wonoroto. Regentschap Kebumen had four districts namely Kebumen, Gedong Tawon, Prembun, Ambal. Regentschap Karanganyar had six districts namely Karanganyar, Gombong, Soka, Petanahan, Puring, Karangbolong. While Regentschap Ledok had 5 districts namely Wonosobo, Kalialang, Leksono, Sapuran, Kaliwiro (De Locomotief, 1874).

There had been no precise information regarding the establishment of when Karanganyar Regency. A book written by Peter Carey quoted a book written by the first Karanganyar Regent, Jayadiningrat. He stated that his rule stood in 1832-1863 (Carey, 2017: 232). Thus, it could be concluded that Karanganyar Regency was founded in 1832. Before becoming the Karanganyar Regency in the Diponegoro War era, this region was included in the Duchy of Remo Djatinegara. The book entitled "Gedenkschrifjt Oorlog op Java Van den 1825 tot 1830" provided much interesting information about months and weeks and days before the arrest of Prince Diponegoro (28 March 1830). The name 'Remo' (sometimes written as 'Rome' ) reappeared in a newspaper during the Javanese War (Javasche Courant, 1828).

According to MM Purbo Hadiwidjoyo, the Remo Duchy centered in Jatinegara Capital city was a merger of two other duchies, the Pucang Duchy and Kaleng Duchy in 1553. The Pucang Duchy was located in East Gombong and Kaleng Duchy in the southern coast. The elderly community of Kedungpuji Village believed that the Pucang Duchy was in the area of their village. The name 'Roma' came from the influence of the Sundanese language 
'Reuma' which means, "The clearing after the forest is cut down" (Hadiwidjoyo, 2012).

The first regent of Karanganyar was K.R.M.A.A. Djojodiningrat. He was succeeded by Raden Adipati Aryo Tirtokusumo. He was the first Chair of the Boedi Oetomo as a result of the Yogyakarta Congress. His position was not widely known by the generations of people in Kebumen and Karanganyar (Hindarto, 2019). Akira Nagazumi wrote about the establishment of Tirtokusumo, "the regent of progress" who thinks far into the future (Nagazumi, 1989: 81). The Karanganyar leadership was continued by Raden Ario Iskandar Tirtokusumo (son of Ario Tirtokusumo). For his services and contribution to the development of his region, the Dutch government gifted him with a "yellow song" as a token of appreciation (De Locomotief, 0611-1931). In his leadership era, Karanganyar became the centre of a famous horse racing (De Preanger Bode, 20-07-1918)

Another contribution was the establishment of the first indigenous people hospital called 'Panti Raga Nirmala' or 'Ziekenhuis Nirmala' founded on 1 January 1919. The laying of its first stone was done on 3 December 1922, while the opening was carried out on 15 June 1924 and followed by a women's hall inaugurated on 30 April 1925 (Bataviasch Nieuwsblad, 1925). In 2018, in the unused former building of the Panti Raga was re- functioned as a Karanganyar Health Center which serves the health needs of the community Hindarto, 2019).

\section{Karanganyar Regency was Broader Than Kebumen}

Karanganyar Regency was a territory of Kedu Residency since 1901 after previously included in Bagelen Residency area after the Java War (1830). However, on 1 July 1928, a reform of the government structure in Central Java was announced. Among several new residencies were Kedu, North Banyumas. There was also the residency of South Banyumas with Cilacap as the capital. The South Banyumas Residency consisted of Regentschap Cilacap (formerly Banyumas Residency area) and Karanganyar (originally Kedu Residency area). A year after the establishment of the South Banyumas Residency, Economic Depression hit the Dutch East Indies region, especially the South Banyumas Residency. Then in 1930, the South Banyumas government was merged with the north into the Banyumas Residency (Zuhdi, 2016: 93).

"Atlas Zendingterreinen van de Gereformeerde Kerken in Nederland" stated that Karanganyar Regency had an area of $791.69 \mathrm{~km}^{2}$ while Kebumen was only 553.64 $\mathrm{km}^{2}$. The composition of the Karangnyar indigenous population was 404,754 and Kebumen 330,652. The total was 735,406 people. In addition to the native population of Europeans, there were 748 people, 3,877 Chinese people, and 71 foreigners in the two districts. If added, the population of these two districts in 1932 was 740,102 people. The report book provides information after explaining the area and population: "Dit terrein is dus niet bizonder groot, maar het is verbazend dicht bevolkt" (This region is not too large but very dense) (Breukelaar, 1932: 8).

Karanganyar Regency earned foreign exchange from harvesting swallow's nests in Karangbolong. Harvesting swallow's nest is not only an economic activity but also a cultural activity because it is related to the people's beliefs about the existence of the goddess of the South Sea god named Ratu Kidul. Therefore, in Karangbolong, a cottage is provided as the centre of the community's ritual activities before harvesting the swallow's nest. Several heirlooms of Karanganyar Regency are stored there (Bataviaasch Nieuwsblad, 1925). However, the formal authority to manage the swallow bird nest harvest in Karang Bolong was only 
handed over from Gouvernement (central government) to Regentschap Karanganjar (Karanganyar Regency) on 1 January 1930 as reported by an article entitled, "De Plaats Der Eetbare Vogelnestjes: Karangbolong (Location of Edible Birds Nest: Karangbolong) (De Sumatra Post, 1931).

\section{The Economic Crisis and the Elimination of Karanganyar Regency: A Sociological Perspective}

As explained above, the tsunami effect of the Economic Depression in America had hit the economy of the Dutch East Indies as well. However, the results of previous research emphasized more on the impact on the economic sector (factories and plantations as well as community income).

The impact of the Economic Depression also touched the government bureaucratic sector. The Dutch East Indies government must carry out several policies, including restructuring the bureaucratic system and cutting salaries and even a plan to eliminate many districts in the Kedu Residency and the Banyumas Residency. Prima Nurarhmi Mulyasari wrote about the plan to eliminate Banyumas and Purwokerto Regencies (Mulyasari, 2010: 27). Not only that the plan of abolition but the removal of the district capital. It was planned that Purwokerto would be abolished as a regency, but it will be made the capital of the Banyumas Regency and Residency.

The planned elimination of several districts in the Banyumas Residency and the Kedu Residency caused some controversies and strong reactions from the district council (De Indische Courant, 2 March 1935). It was feared that the area that was once deserted had become lonelier and the economy became paralyzed and unemployment increased. However, despite those arguments, it was up to being unanimously agreed. "As of January 1936, several regencies in Central Java Province, namely Purwokerto, Karanganyar, Kutoarjo and Batang were abolished" (Mulyasari, 2010: 29). By merging the two regencies in the Banyumas Residency area on 1 January 1936, the Banyumas Residency only has four regencies namely, Cilacap, Banjarnegara, Purbalingga and Banyumas.

Likewise, Karanganyar Regency suffered a similar fate, "opheffing" (deleted) and "samenvoeging" (combined). Karanganyar Regency would be combined into a district in the Kebumen Regency area. The district council in Banyumas reacted similarly as Karanganya authorities to the status of "opheffing" (abolished) and "samenvoeging" (merged). Some of the main underlying factors of the objection to the elimination and incorporation of the district by some members of the Regency Council were a historical aspect that was not considered (Het Nieuws, 9 December 1935). The District Council made the existence of an oil factory in Karanganyar as an argument to reject the abolition because of its contribution to economic development. Nevertheless, all the resistance and rejection were useless because the elimination and incorporation not negotiable.

In a newspaper article entitled, "Opheffing van Regentschappen: Ontwerpen voor Karanganjar, Batang en Poerwokerto" (Elimination of Regencies: Draft for Karanganyar, Batang and Purwokerto), it was stated that the government had given a Memorie van Toelechting (memorandum of explanation) on changes in the area if it is already combined. Karanganyar Regency which covered an area of $792 \mathrm{~km}^{2}$ and had a population of 407,000 people and Kebumen which had an area of $554 \mathrm{~km}^{2}$ with a population of 333,200 after being combined would have an area of $1345 \mathrm{~km}^{2}$ and a population of 740,200 (Soerabaiasch Handelsblad, 1935).

What were the underlying reasons for the implementation of "opheffing" (deleted) 


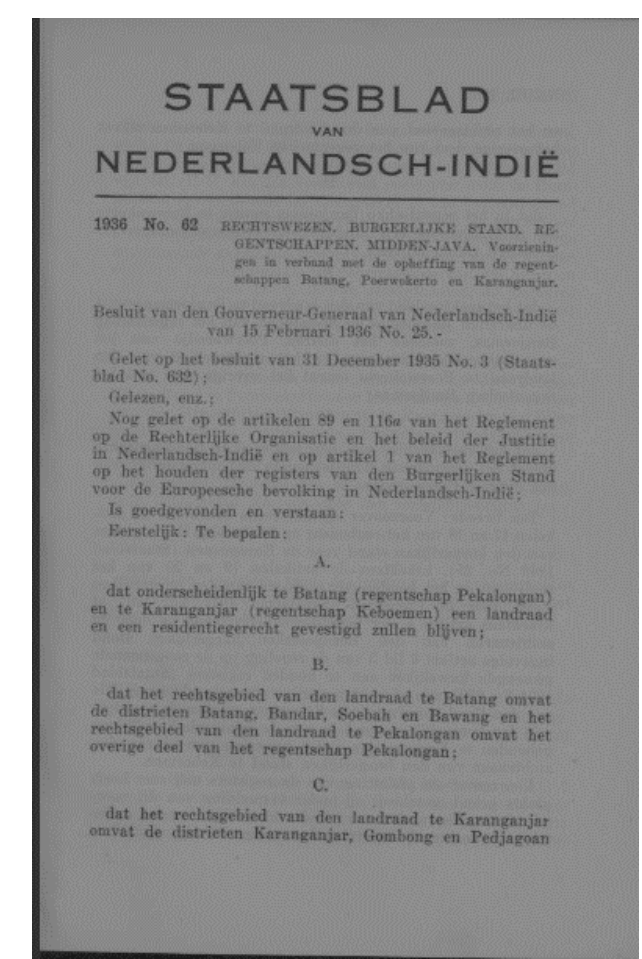

Figure 1. "Staatsblad Van Nederlandsch Indie Over Het Jaar 1936," 1937

and "samenvoeging" (combined) in many districts including Karanganyar Regency? Savings or efficiency! As explained in the newspaper called "Het Nieuws" (13 December 1935), "Savings," which can be obtained from the merger is estimated to save 97,000 fluorine per year. The elimination of the district would undoubtedly reduce the budget burden to pay several regents, patih, and assistant wedana along with other government employees. The abolition of Batang Regency, Purwokerto, and Karanganyar was stipulated in "Staatblad van Nederlandsch Indie 1936 No. 62" signed by the Secretary-General JM Kiveron on behalf of the Governor of the Dutch East Indies at that time, De Jonge. This gazette was issued on 25 February 1936 (Staatsblad 1936, 1937).

Historically, 1 January 1936 was the official day of enforcement of Staatblad van Nederlandsch Indie 1936 No. 62 in which Karanganyar Regency became Kebumen District. However, the data above was once considered the anniversary of the Kebumen District for many years until the issuance of Kebumen District Regulation No. 3 of 2018 concerning the Anniversary of the Kebumen District. It was initially set on 1 January 1936 and was changed to 21 August 1629.

In the sociological perspective, in every occurring social change, there is a power that drives the process of change. There is no standalone event of social change. It is always related to the structure and agency as well as factors outside the structure and agency. The causal factor that occurs from within the system is called an "endogenous process," while if the causal factor that occurs from outside is called the "exogenous process" (Sztompka, 2014: 19). Even though there is no single factor in the occurrence of a social change, there are dominant factors that can be traced. As Sztompka said, "Sociologists must try to find which factors are the most important causes of change; what is the 'main driver' of the social process" (Sztompka, 2014: 20). With the above perspective, the abolition of Karanganyar's status as a regency and combined into one of the district areas in Kebumen Regency as driven by a dominant external factor or "exogenous processes". While in terms of planning by the agents of change, in this case, the Dutch East Indies government, the decision to eradicate Karanganyar and merger into the Kebumen area was something that was outside of previous planning. In a sociological perspective, it is called "unintended change" or "unplanned change," an opposite of "intended change" or "planned change" (Soekanto, 2014: 272-273).

From the sociological perspective, the elimination of Karanganyar Regency into the Kebumen Regency was included in the category of 'unplanned change.' The government is required to respond to overcome economic shocks due to the Economic Depression. If the private sector responds to the impact of the Economic 
Depression by reducing land and labor and even shutting down its companies (as the bankruptcy of many sugar factories), the government made efforts to budget efficiency by removing a number of districts in several residencies, both the Kedu Residency and the Banyumas Residency. Economic Depression events centered in America as the "epicenter of the economic earthquake" spread to Europe and a number of its colonies in Asia, including exogenous forces that caused unpreparedness and the emergence of unplanned socio-economic changes with all its excesses. By using the Tension Theory approach from Robert Merton, the efforts of the Dutch East Indies government as a political institution have taken the form of innovation adaptation (innovation). It is a form of adaptation that is different from the existing norms, so that it must take on extraordinary political policy by removing many regencies, including Karanganyar.

\section{Why was Karanganyar, which is wider than Kebumen, was written off as a Regency?}

There is one remaining question, why was Karanganyar abolished even though in terms of territory, Karanganyar was larger in area than the neighboring Kebumen Regency? Economically, Karanganyar has the potential to be reliable due to swallowing nest harvest and a coconut oil factory. This question is not easy to answer. However, the writer assumes that the election of Karanganyar as an abolished regency instead of Kebumen Regency was based more on historical reasons, namely the role and contribution of the Aroengbinang dynasty in ending the Java War in the West Bagelen region, especially Panjer. This assumption was based on a statement made by the Governor of Central Java, De Vos, during his speech in R.A.A. Aroengbinang VII's resignation and the establishment of
RAA Sosrohadiwidjojo (Aroengbinang VII's younger brother) as the Kebumen Regent. He held the Aroengbinang VIII title, relating to the abolition of Karanganyar Regency and its incorporation into part of Kebumen Regency.

An article entitled, "Een Glorieus Regentengeslacht" (The Noble Regent's Family) which contained a speech from the Governor of Central Java De Vos to the Regent of Arung Binang VII who resigned and the appointment of Arung Binang VIII as the new Kebumen regent, in one of the remarks. It was addressed to Arung Binang VII and stated the following: "All residents in your district know that Keboemen Regency is the seat of the head of government born from the Aroeng Binang family line, whose lineage is based on the authority of the Dutch government. It cannot be touched" (De Locomotief, 17 February 1936).

Historical reasons in the form of the role and contribution of Arungbinang IV in helping to quell the Java War and the resistance of Prince Diponegoro's followers in the West Bagelen region, especially Panjer, which was later replaced by Kebumen,

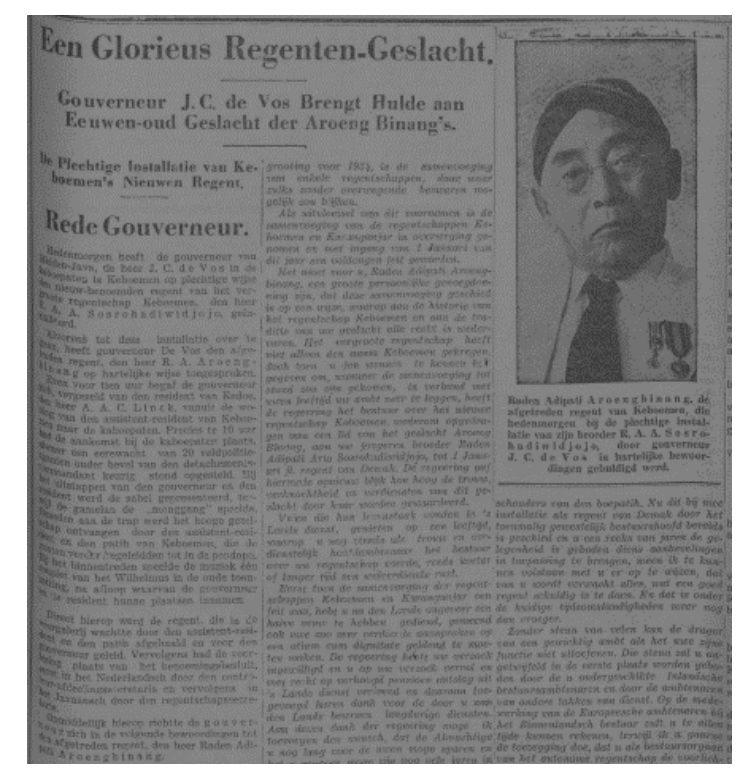

Figure 2. De Locomotief, 17 February 1936 
established its role as a regency in the removal of other regencies during the great depression. The term 'onaantastbaar' (cannot be touched) emphasize the historical authority of the Aroengbinang family towards the formation of Kebumen Regency.

\section{Karanganyar, Post Merger with Kebumen Regency}

What is the status of Karanganyar Regency after 'opheffing' (deleted) and 'samenvoeging' (combined)? Some changes could still be traced through a number of newspaper reports in the Dutch East Indies. The Karanganyar Regent, R.A.A Iskandar Tirtokusumo, who initially served in Karanganyar, was transferred to Demak, as reported by De Indische Courant (2 March 1936). "The Regent of Demak has been appointed. his name is R.A.A. Iskandar Tirtoekoesoemo. Hewas originally the Regent of Karanganyar." Likewise, the management of swallow nests which was initially the authority of Karanganyar Regency was now in the authority of Kebumen Regency (De Indische Courant, 1937).

Since 1936 or 1937, it seemed that the pandanus woven industry began to develop in Karanganyar. In an article written by Ir. R. Soepardi, Head of the Industrial Consultation Office, South Central Java, entitled, "De Aspecten Der Klein-Industrie op Java" (Micro Industry Aspects in Java explained the role of Karanganyar - a district that had just been united with Kebumen District - in supporting the woven hat industry (Het Nieuws, 1936 ).

\section{Conclusion}

Viewed from a sociological perspective, the abolition of the Karanganyar Regency status and its combination into the Kebumen Regency region was not a decision and historical event that stood alone. It was highly related with events originating from exogenous factors (external forces). The exogenous factor that drives unplanned change was malaise, which shook and caused structural changes in all fields. We did not find any sign of incompetent and mismanaged government administration. There was no endogenous force that encouraged the elimination of Karanganyar Regency.

The impact of removing the status of Karanganyar Regency was immediately seen in how the sources of economic income in the Karanganyar area were managed by the Kebumen Regency. It had gained status as a 'Groote Regentschap Keboemen' or Expanded Kebumen Regency because the Karanganyar geographical area was included as the Kebumen Regency. Various rejections from the Karanganyar Regency Council could not defer the plans and decisions of the Dutch East Indies government to remove (opheffing) Karanganyar Regency status and merge (samenvoeging) it into the Kebumen Regency. The authority of Karanganyar as a regency city was reduced to the authority of a sub-district city under Kebumen Regency. The 20th Century became an ending to the story of a regency called Karanganyar - as Purwokerto and Batang - and morphed into a new story of a subdistrict. Only Batang regency succeeded in re-establishing its historical roots into a regency in 1966. Through the sociohistorical study of Karanganyar in the colonial era, it was hoped that knowledge of the past would help to reconstruct Karanganyar District in the Kebumen Regency today.

\section{Declaration of Ownership}

This article is our original work.

\section{Conflict of Interest}

There is no conflict of interest to declare in this article. 


\section{Ethical Clearance}

This study was approved by the institution.

\section{References}

Ahuja, R. (1992). Social problem in India. Rawat Publications.

Basundoro, P. (2013). Sisi terang kolonialisme Belanda di Banyumas dalam membedah sejarah dan budaya maritim merajut $k e-$ Indonesiaan. UNDIP Press.

Breukelaar, W. G. (1932). L.G Atlas Zendingterreinen van de Gereformeerde Kerken in Nederland. Zomer en Keuning's Uitgeversmaatschaappij.

Crafts, N., \& Fearon, P. (2013). The great depression of the 1930s: Lessons for today. Oxford University Press.

Carey, P. (2017). Sisi lain Diponegoro: Babad kedung kebo dan historiografi perang Jawa. KPG.

Badan Pusat Statistik. (2019). Kebumen dalam angka. Badan Pusat Statistik Kabupaten Kebumen.

Margana, S., \& Nursam, M. (2010) Kotakota di Jawa: Identitas, gaya hidup dan permasalahan sosial. Ombak.

McNesse, T. (2010). The great depression 19291938. Chelsea House.

Macionis, J. J. (2014). Sociology. Pearson.

Merton, R. K. (1968). Social theory and social structure. Free Press.

Mulyasari, P. N. (2014). Modernisasi dan tata ruang Purwokerto 1900-1935. Jurnal Patrawidya, 15(4), 605-620.

Nagazumi, A. (1989). Bangkitnya nasionalisme Indonesia: Budi Utomo 1908-1918. Grafiti Pers.

Nieuman, L. W. (2013). Metodologi penelitian sosial: Pendekatan kualitatif dan pendekatan kuantitatif. PT. Index.
Padmo, S. (1991). Depresi 1930-an dan dampaknya terhadap Hindia Belanda. Jurnal Humaniora, 3(2), 147-156. https://doi. org/10.22146/jh.2159

Paulus, B. (1917). Encyclopaedia van Nederlandsch Indie, eerste Deel A-C. Gravenhage- Martinus Nijhoff.

Perry, M. (2017). Peradaban barat: Dari zaman kuno sampai zaman pencerahan. Kreasi Wacana.

Ritzer, G. (2004). Teori sosiologi klasik sampai perkembangan terakhir postmodern. Pustaka Pelajar.

Stuers, F. V. A. R., \& Lange, H. M. (1874). Gedenkschrifjt oorlog op Java Van den 1825 tot 1830. Johannes Muller.

Sztompka, P. (2011). Sosiologi perubahan sosial. Prenada.

Shlaes, A. (2007). The forgotten man: A new history of the great depression. Harper Collins.

Siswoyo, T., Ekwandari, Y. S., \& Wakidi, W. (2017). Pengaruh malaise terhadap perkebunan kolonial di Hindia Belanda tahun 1930-1940. Jurnal Pendidikan dan Penelitian Sejarah PESAGI, 5(9).

Sumardjan, S. (2009). Perubahan sosial di Yogyakarta. Komunitas Bambu.

Staatsblad van Nederlandsch Indie over het jaar 1936. (1937). Landsdrukkerij.

Sukardi, T. (2014). Tanam paksa di Banyumas: Kajian mengenai sistem, pelaksanaan dan dampak sosial ekonomi. Pustaka Pelajar.

Turner, J. H. (2014). Theoretical sociology: A concise introduction to twelve sociological theories. Sage.

Tonkiss, F. (2006). Contemporary economic sociology: Globalisation, production. Inequality. Routledge.

Weber, M. (2006) Etika protestan dan spirit kapitalisme. Pustaka Pelajar. 
Wajcman, J., \& Nigel, D. (2017). The sociology of speed: Digital, organisational and social temporalities. Oxford Unversity Press.
Zuhdi, S. (2016). Cilacap 1830-1942: Bangkit dan runtuhnya suatu pelabuhan di Jawa. Ombak. 